\title{
Fatigue behavior study of a dense graded HMA using the four point bending beam test aided by an in-situ instrumentation at BR-116/RS, Brazil
}

\author{
Gracieli Bordin Colpo ${ }^{1}$, Lélio Antônio Teixeira Brito ${ }^{2}$, Dionísio Doering ${ }^{3}$, \\ ${ }^{1}$ Federal University of Rio Grande do Sul - Brazil, grabc@hotmail.com \\ ${ }^{2}$ Federal University of Rio Grande do Sul - Brazil, lelio.brito@ufrgs.br \\ ${ }^{3}$ State University of Rio Grande do Sul and Slac National Laboratory - Brazil, dionisio.doering@ufrgs.br \\ ${ }^{4}$ North Carolina State University - United States, dmarti23@ncsu.edu \\ ${ }^{5}$ State University of Rio Grande do Sul - Brazil, nplhilgert@gmail.com \\ ${ }^{6}$ Federal University of Rio Grande do Sul - Brazil, marlova.johnston@ufrgs.br \\ ${ }^{7}$ Federal University of Rio Grande do Sul - Brazil, jorge.ceratti@ufrgs.br
} Douglas Martins Mocelin ${ }^{4}$, Ana Paula Hilgert ${ }^{5}$, Marlova Johnston ${ }^{6}$, Jorge Augusto Pereira Ceratti

\section{Recebido:}

7 de dezembro de 2018

Aceito para publicação:

1 de junho de 2019

Publicado:

15 de maio de 2020

Editor de área:

Francisco Thiago Aragão

\section{Keywords:}

IDT fatigue test,

Four point bending test,

Pavement instrumentation,

Fatigue performance.

\section{Palavras-chaves:}

Ensaio de fadiga IDT,

Ensaio de flexão em quatro pontos, Instrumentação em pavimentos,

Desempenho à fadiga.

DOI:10.14295/transportes.v28i2.1907

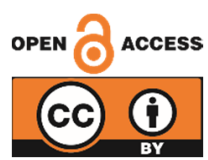

\begin{abstract}
Fatigue is characterized by structural deterioration of a material when subjected to a state of repeated stress-strain cycles, thus resulting in cracking of the pavement and eventual failure after a sufficient number of cycles. The laboratory test commonly employed in Brazil to analyze the fatigue life is the indirect tensile test (IDT) under controlled stress. An alternative test method is the four-point bending beam test (4PBBT), which leads the material to a more realistic stress-state. This work examined the fatigue behavior of an asphalt mixture with polymer-modified binder (PG76-11) using both IDT and 4 PBBT. A road segment at BR-116/RS was instrumented to monitor mechanic responses in the asphalt layer allowing the evaluation of the material under real traffic, and through real-time monitoring, enabling a better understanding of the distress levels in the structure. The results also demonstrate a closer relation between the 4PBB tests with in-service pavement fatigue development.
\end{abstract}

\section{RESUMO}

A fadiga é caracterizada pela deterioração estrutural de um material quando submetido a repetidos esforços de tensão-deformação. $O$ ensaio laboratorial comumente empregado no Brasil para análise de fadiga em misturas asfálticas é o ensaio de tração indireta (IDT). Como alternativa ao ensaio IDT, o ensaio de flexão em quatro pontos (4PBBT) submete o material a um estado de tensões mais realístico em relação ao campo. Este trabalho avaliou o comportamento à fadiga de uma mistura asfáltica com ligante modificado por polímero (PG76-11) usando os ensaios IDT e 4PBBT. Um segmento da rodovia BR-116/RS, pavimentado com o mesmo material, foi instrumentado para monitorar as respostas mecânicas na camada asfáltica, permitindo a avaliação do material sob condições de tráfego real, e através do monitoramento ao longo do tempo, permitindo meIhor entendimento do desgaste estrutural. Em relação aos ensaios laboratoriais, o ensaio 4PBBT apresentou uma melhor relação com o observado em campo.

\section{INTRODUCTION}

The fatigue cracking is recognized as one of the main distress types in asphalt concrete pavements (Pell et al., 1961; Rowe, 1996; Harvey et al., 1995; Di Benedetto et al., 2004). This phenomenon occurs due to the accumulation of damage under the effect of repeated traffic loading. The tensile strain developed in the bottom of the wearing course leads the layer to cracking and consequent loss of structural capacity. 
Various laboratory testing methods have been developed to characterize the fatigue response of asphalt concrete mixtures. In Brazil, the test commonly employed to analyze the fatigue life of asphalt mixtures is the indirect tensile test by diametral compression in cylindrical samples (IDT). This test is relatively simple to conduct and low cost, but feature some acknowledged disadvantages, such as permanent deformation on the loading strips due to high shear stresses, impossibility of separating damage due to fatigue from damage due to excessive creep flow for testing in inelastic materials, such as asphalt, and underestimation of the fatigue life (Tangela et al., 1990; Di Benedetto et al., 2004). Nonetheless, four point bending beam tests are recognized to display a better ability to simulate field conditions (Tayebali et al., 1994). In Brazil, the four point bending beam test has being employed for asphalt mixtures fatigue characterization in various research projects, such as Colpo (2014), Klinsky et al. (2014), Melo (2014), Ceratti et al. (2017) and Bessa (2017).

The monitoring of stresses and strains developed in pavement structures is of interest to pavement researches and engineers for a proper understanding of their structural behavior, which is crucial to pavement design, performance prediction and road management systems (Zejiao, Yiqiu and Meili, 2012). Measuring of the mechanical and environmental response of an in-service segment through instrumentation allows the comparison with laboratory behavior of the same asphalt mixture.

Pavement instrumentation can be an important tool for monitoring in-service material performance, structural responses under actual environmental and loading conditions, and also assist in the calibration of models (Leiva-Villacorta and Timm, 2012). Various instrumentation efforts pursued such purpose, allowing the validation and calibration of models that are actually used in mechanistic-empirical pavement design methods (Timm, Priest and McEwen, 2004; Priest, 2005; Ullidtz et al., 2006).

In tolled roads the development of a significant superficial cracked area is limited by the control agencies and are subject to a penalty. Hence, pavement distress evolution depends on deflection control to help evaluating road structure as surfacing works are recurrent and the cracking assessment clouded. Because such procedure is affected by all layers' resilient behavior interdependence and is influenced by weather, testing protocol and loci as well as equipment, tools to aid engineers to better evaluate the pavement structural condition ought to be investigated. All considered, a proper fatigue performance model becomes vital to anticipate the right moment of an intervention or repair in the structure, thus allowing adequate network managing.

This research was divided into two stages: field instrumentation of a tolled road segment in a federal highway and laboratory fatigue tests by means of IDT and 4PBB tests. Since the relation between the field and laboratory response is considered a challenge for road engineers this work aims to contribute to a better outlook on the instrumentation support towards such effort.

\section{BACKGROUND}

Fatigue phenomenon is considered the main mechanism of distress in flexible pavements (Pell et al., 1961; Preussler et al., 1981; Tangella et al., 1990; Matthews et al., 1993; Harvey et al., 1995; Kim et al., 1997; Di Benedetto et al., 2004; Tapsoba et al., 2013; Mateos et al., 2017), and is highly dependent not only on material characteristics, but also on traffic and environmental conditions, which makes its interpretation and modeling complex. 
The asphalt mixtures fatigue behavior is being studied throughout the years, with different considerations and approaches. Some approaches are purely empirical and observational, where the number of cycles at failure is related to the input of strain amplitude or stress level in a cyclic test. Other approaches include mechanistic elements and embodies a more phenomenological view, relating the number of cycles at failure with parameters such as initial stiffness, dissipated energy, fracture mechanics and continuum damage.

The classic approach to access the number of cycles at failure $\left(\mathrm{N}_{\mathrm{f}}\right)$ for a given tensile strain amplitude or tensile stress level for asphalt mixture layers are so-called Wöhler curves (Equation 1 and 2).

$$
\begin{aligned}
& N_{f}=a * \varepsilon_{t}^{-b} \\
& N_{f}=c * \sigma_{t}^{-d}
\end{aligned}
$$

where: $\mathrm{N}_{\mathrm{f}}$ :

Number of cycles at fatigue failure;

Et: $\quad$ Tensile strain amplitude;

$\sigma_{t}: \quad$ Tensile stress level;

a, b, c, d: Regression coefficient.

Dissipated energy concept has been successfully used in the asphalt fatigue life prediction (Shen and Carpenter, 2005, 2007; Shen et al., 2006; Dondi et al., 2013; Subhy et al., 2017). Those methods are based on the assumption that the energy is absorbed by the material as damage, and the number of loading cycles at failure is related to the amount of energy dissipated during the test (Xiao, 2006).

Viscoelastic materials, when subjected to cyclic loading, present a hysteresis loop, once the loading and unloading path are not coincident due the viscoelasticity. The area inside this loop corresponds to the dissipated energy on that load cycle (Rowe, 1996; Ghuzlan and Carpenter, 2000), and can be calculated by Equation 3.

$$
D E_{\mathrm{i}}=\pi * \varepsilon_{i} * \sigma_{i} * \sin \left(\varphi_{i}\right)
$$

where: $\quad \mathrm{DE}_{\mathrm{i}}$ : $\quad$ Dissipated energy at load cycle $\mathrm{i}$;

عi: $\quad$ Strain amplitude at load cycle i;

бi: $\quad$ Stress amplitude at load cycle i;

$\varphi$ i: $\quad$ Phase shift between stress and strain at load cycle i.

The classic fatigue models can be related to the initial dissipated energy as follows (Equation 4).

where: e, f: Regression coefficient.

$$
N_{f}=e^{*} D E_{i}^{-f}
$$

\subsection{Fatigue Field Monitoring}

For a proper construction or rehabilitation design of pavement structures, it is necessary to address the materials behavior under a wide range of loads and environmental conditions, such as temperature. To develop an adequate performance model for a given structure, it is mandatory to understand the differences between laboratory performance tests and actual field responses. In this sense, field instrumentation can be a powerful tool to better understand the actual response of the pavement under different conditions, which is not possible to simulate in laboratory (Al-Qadi and Nassar, 2003). 
Pavement instrumentation has being used in several countries with satisfactory results, that helps to calibrate and validate models and pavement design methods (Brown, 1977; Tabatabafe and Sebaaly, 1990; Van Deusen et al., 1992; Silva e Motta, 1999; Priest and Timm, 2006; Mateos et al., 2011). Most of the studies, nonetheless, are carried out in experimental sections and controlled loading environment.

Garg et al. (2018) used field instrumentation data to develop a HMA fatigue model based on the ratio of dissipated energy change (RDEC). Various studies (Rowe, 1996; Ghuzlan and Carpenter, 2000; Subhy et al., 2017) have shown that RDEC, defined as the change of the dissipated energy between two cycles divided by the dissipated energy of previous cycle, provides a better indication of damage induced by the repeated load. This fatigue model for HMA is used in airport pavement thickness design software FAARFIELD.

Leandri et al. (2013) observed that simulations of longitudinal and transversal strains provide a good fit with the registered wave pulse, in terms of both shape and peak values. The simulated vertical stress at the bottom of asphalt concrete layer well reproduce the peak values even if the shape is not exactly replicated, the tails of the registered pulse decrease more sharply than simulations.

Silva e Motta (1999) captured the Brazilian experience with pavement instrumentation and accredited that the first road instrumentation to an experiment in 1976, aiming to analyze pozzolanic mixtures in the highway BR-101, in Santa Catarina state. Gonçalves (2002) used pavement-embedded instrumentation to evaluate six experimental segments subjected to a heavy vehicle simulator in an accelerated pavement loading facility on the Pavement Laboratory at Federal University of Rio Grande do Sul (LAPAV-UFRGS). Bastos (2016) also instrumented a pavement segment subjected to a heavy vehicle simulator, using strain gages, pressure cells, temperature and moisture sensors at Ceará state.

\section{EXPERIMENTAL INVESTIGATION}

The instrumentation process of the road segment and laboratory tests are described below. A bespoken data collection system with embedded signal processing and instruments signal-conditioners are detailed elsewhere (Ceratti et al., 2017).

\subsection{Field instrumentation}

The structure of test section selected consists of a flexible pavement with a bituminous layer of a hot mix asphalt (HMA) with polymer-modified binder ( $8 \mathrm{~cm}$ thickness), a dense-graded aggregate base $(15 \mathrm{~cm})$ and granular subbase $(30 \mathrm{~cm})$ over a clayey subgrade.

Sensors embedded in pavement sections have proved useful in providing measured responses as a basis of comparison. Various researches have instrumented pavement layers using strain gages and pressure cells to measure dynamic response to load in the form of strains and pressures (Timm, Priest and McEwen, 2004; Gonçalves, 2002; Leandri et al., 2013; Chaves et al., 2016). Following the same line of work, a road segment on BR-116/RS, in southern Brazil, was instrumented with these sensors in the bottom of asphalt wearing course.

Sensors were selected in accordance with literature and the researchers experience and included six strain gages (SG) (Figure 1a), two pressure cells (PC) (Figure 1b) and six thermistors (Figure 1c). One of the pressure cells (model Geokon Earth Pressure Cell) featured a $1.0 \mathrm{MPa}$ nominal maximum pressure (PC1) and the other 2.5 MPa (PC2); the strain gages (model Kyowa 
KM-120-120-H2-11-W1M) were oriented to measure longitudinal, transverse and $45^{\circ}$ strain, and the thermistors (model LM35) have the temperature range from $-55^{\circ} \mathrm{C}$ to $+150 \stackrel{\circ}{\circ} \mathrm{C}$ with \pm $0.5^{\circ} \mathrm{C}$ accuracy.

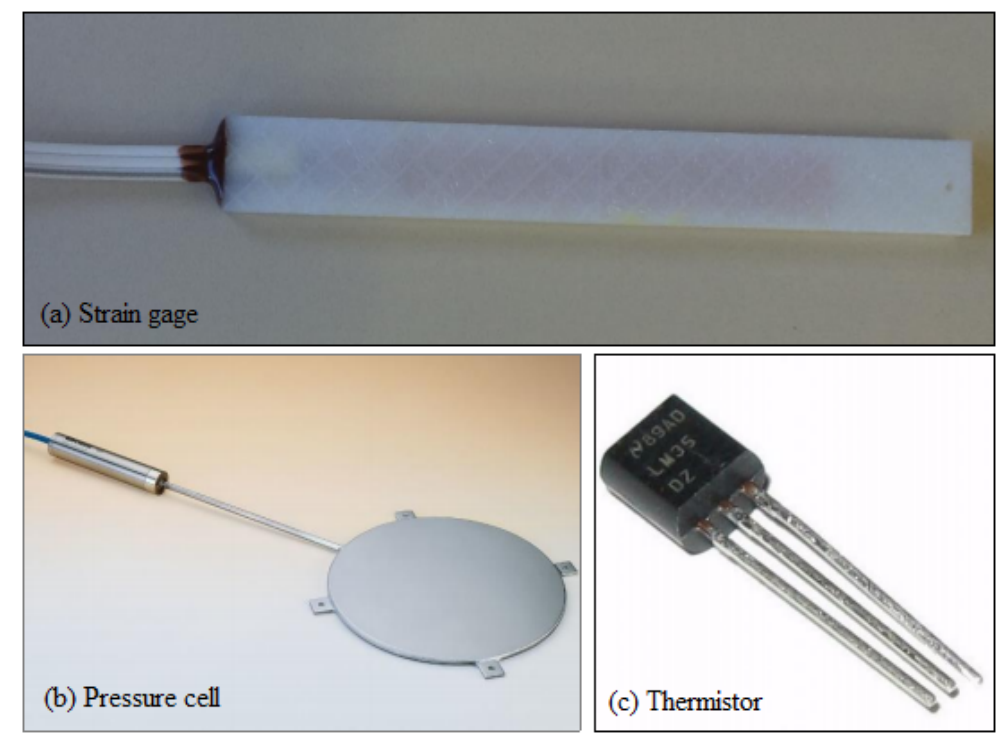

Figure 1. Sensors used on the experimental segment

All the sensors were installed in the bottom of the pavement wearing course. The first set (PC2 + 3 SG) was spaced $5 \mathrm{~m}$ apart longitudinally from the second set (PC1 + $3 \mathrm{SG}$ ) and located under the external wheel path of the external road lane. Figure 2 shows the sensor layout along the external wheel path.

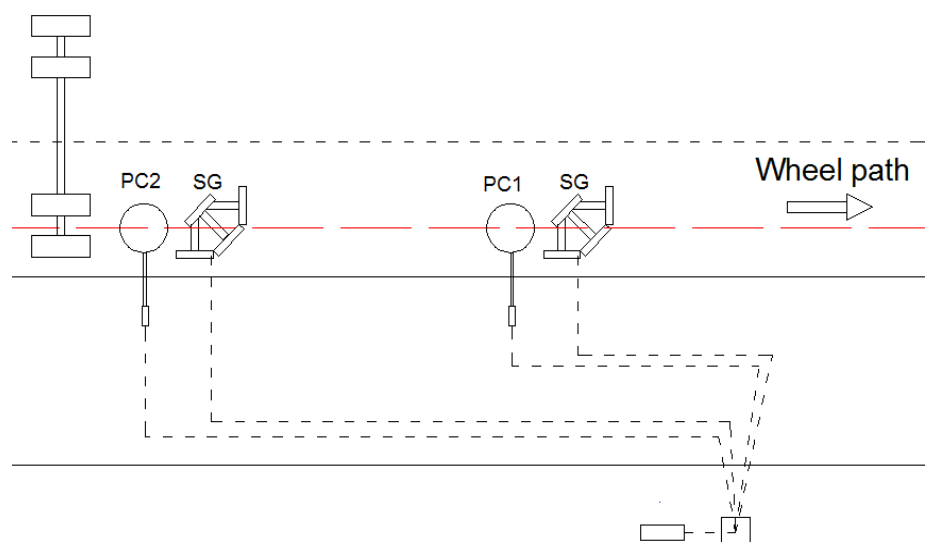

Figure 2. Sensors installation layout

A custom data acquisition system (DAS) was developed as part of this research. The DAS performs signal conditioning, analog signal filtering and amplification, digitization and data preprocessing before sending it to an embedded single board computer for storage. The pre-processing implements a high pass filter to remove base line level variations (caused mainly due to temperature variations) and a trigger algorithm that sends a flag indicating the start of a dynamic event. The event flag is set when the signal variation is higher than a user defined threshold. The system samples the analog signals at a rate of 450 points per second, per channel. 


\subsection{Laboratory tests}

To evaluate the laboratory performance two test configurations were used, IDT and 4PBB. The specimens required for the tests were cored direct from the field, both cylindrical (for IDT tests) and prismatic (for the 4PBB tests). The procedure allowed evaluating the actual in situ density condition, as mixtures produced in an asphalt plant and in the laboratory may display differences in performance (Rahbar-Rastegar and Daniel, 2016). Binder content for the hot mix asphalt was $5.24 \%$ by weigh and featured apparent specific gravity of 2.289 .

The 4PBB test were carried out under controlled strain mode of 400 microstrains $(\mu \varepsilon), 500$ $\mu \varepsilon$ and $600 \mu \varepsilon$. In this study, a repeated sinusoidal loading at a frequency of $10 \mathrm{~Hz}$ was used. All tests were performed in a temperature-controlled chamber at $20 \pm 0.5^{\circ} \mathrm{C}$. The control and data acquisition software (UTS015) measured the deflection of the beam specimen, computed the strain peak to peak in the specimen and adjusted the load applied by the loading device as per AASHTO T321 (2014).

The test apparatus also recorded load cycles, applied strain peak to peak, and beam deflections. Failure was assumed to occur when the stiffness reached half of its initial value, which is determined from the load at approximately 50 repetitions; the test was terminated automatically when stiffness was reduced by $50 \%$. The dissipated energy, tensile stress and strain and flexural stiffness of fatigue beam are determined by Equations 3, 5, 6 and 7 with the software UTS015 (AASHTO T321, 2014).

$$
\begin{gathered}
\sigma_{t}=\frac{P^{*} L^{*} 1000000}{b^{*} h^{2}} \\
\varepsilon_{t}=\frac{12 * \delta^{*} h}{3 * h^{2}-4^{*} a^{2}} \\
S=\frac{1000 * \sigma_{t}}{\varepsilon_{t}}
\end{gathered}
$$

where: $\quad \sigma_{\mathrm{t}}: \quad$ Tensile stress amplitude $(\mathrm{kPa})$;

P: $\quad$ Peak force $(\mathrm{kN})$;

L: $\quad$ Support span width $(\mathrm{mm})$;

b: $\quad$ Average beam width $(\mathrm{mm})$;

h: $\quad$ Average beam height $(\mathrm{mm})$;

$\varepsilon_{\mathrm{t}}: \quad$ Tensile strain amplitude $(\mu \varepsilon)$;

$\delta$ : $\quad$ Peak deflection at the center of beam $(\mathrm{mm})$;

a: $\quad$ Loading span width $(\mathrm{mm})$;

S: $\quad$ Flexural stiffness (MPa).

Note the validity of the equations above assume homogeneity of a linear viscoelastic, isotropic material. These equations consider the most stressed fiber in the bottom of the specimen, which should be the more stressed fiber, and consider the stresses/strains to be linear across the center transversal section of the specimen. Furthermore, the assumptions involved in the equations above are good approximations in the first cycles whilst damage is reduced and material integrity is unchanged. Although such considerations limit a fatigue study, they are rather simple approaches for application in the present research. The hysteresis loop is calculated using these assumptions and so are calculated for the most stressed fiber.

The IDT was conducted under controlled stress mode of about $10 \%, 20 \%, 30 \%, 40 \%$ and $50 \%$ to the monotonic indirect tensile strength (ITS = $1.43 \mathrm{MPa}$ ). In this study, a cyclic haversine 
loading at $1 \mathrm{~Hz}$ frequency, with pulse time of $0.1 \mathrm{~s}$ and $0.9 \mathrm{~s}$ of rest, was used. The failure criteria adopted was $50 \%$ reduction in the initial resilient modulus. All tests were performed in a temperature-controlled chamber at $20 \pm 0.5^{\circ} \mathrm{C}$. The tensile stress and resilient modulus (MR) are determined by Equations 8 and 9.

$$
\begin{gathered}
\sigma_{t}=\frac{2 * P}{\pi * d * h} \\
M R=\frac{P}{\Delta * h} *(0.9976 * \mu+0.2692)
\end{gathered}
$$

where: $\quad \sigma_{\mathrm{t}}$ : Tensile stress level (MPa);

P: $\quad$ Peak force (N);

$\mathrm{d}$ : $\quad$ Average specimen diameter (mm);

h: $\quad$ Average specimen height ( $\mathrm{mm})$;

MR: $\quad$ Resilient modulus (MPa);

$\Delta: \quad$ Resilient displacement of the specimen ( $\mathrm{mm}$ );

$\mu$ : Coefficient of Poisson.

\section{RESULTS}

\subsection{Fatigue life}

The results obtained for 4PBB fatigue tests are shown on Table 1 . The results presented are the average of three specimens and the coefficients of variation (COV) are also shown Figure 3 presents the fatigue plot of 4 PBB fatigue tests considering tensile strain and initial dissipated energy.

\begin{tabular}{|c|c|c|c|c|c|c|c|c|c|c|c|}
\hline \multirow[b]{2}{*}{ Sample } & \multirow[b]{2}{*}{$\begin{array}{l}\text { Air voids } \\
\text { (\%) }\end{array}$} & \multirow{2}{*}{$\begin{array}{c}\text { Strain } \\
\text { ampli- } \\
\text { tude } \\
(\mu \varepsilon)\end{array}$} & \multicolumn{3}{|c|}{ Initial flexural stiffness } & \multicolumn{3}{|c|}{ Initial dissipated energy } & \multicolumn{3}{|c|}{ Number of cycles at failure $\left(\mathrm{Nf}_{50 \%}\right)$} \\
\hline & & & $\begin{array}{l}\text { Initial flexural } \\
\text { stiffness (MPa) }\end{array}$ & Average & $\begin{array}{l}\text { COV } \\
(\%)\end{array}$ & $\begin{array}{c}\text { Initial } \\
\text { dissipated } \\
\text { energy }\left(\mathrm{J} / \mathrm{m}^{3}\right)\end{array}$ & Average & $\operatorname{cov}(\%)$ & $\mathrm{Nf}_{50 \%}$ & Average & $\operatorname{cov}(\%)$ \\
\hline 1 & 4.2 & & 5403 & & & 397 & & & $1.80 \mathrm{E}+05$ & & \\
\hline 2 & 4.1 & 400 & 5507 & 5455 & 6.3 & 371 & 393 & 5.3 & $3.00 \mathrm{E}+05$ & $2.73 E+05$ & 30.2 \\
\hline 3 & 4.2 & & 6047 & & & 412 & & & $3.38 \mathrm{E}+05$ & & \\
\hline 4 & 4.3 & & 5546 & & & 613 & & & $1.01 \mathrm{E}+05$ & & \\
\hline 5 & 4.3 & 500 & 5552 & 5592 & 1.3 & 605 & 615 & 1.9 & $1.08 \mathrm{E}+05$ & $1.05 \mathrm{E}+05$ & 3.5 \\
\hline 6 & 4.3 & & 5677 & & & 628 & & & $1.06 \mathrm{E}+05$ & & \\
\hline 7 & 4.1 & & 5519 & & & 871 & & & $4.34 \mathrm{E}+04$ & & \\
\hline 8 & 4.1 & 600 & 5542 & 5560 & 0.9 & 901 & 895 & 2.4 & $5.14 \mathrm{E}+04$ & $4.99 E+04$ & 11.9 \\
\hline 9 & 4.1 & & 5618 & & & 912 & & & $5.51 \mathrm{E}+04$ & & \\
\hline
\end{tabular}

Table 1 - Results of fatigue test for 4PBB testing method
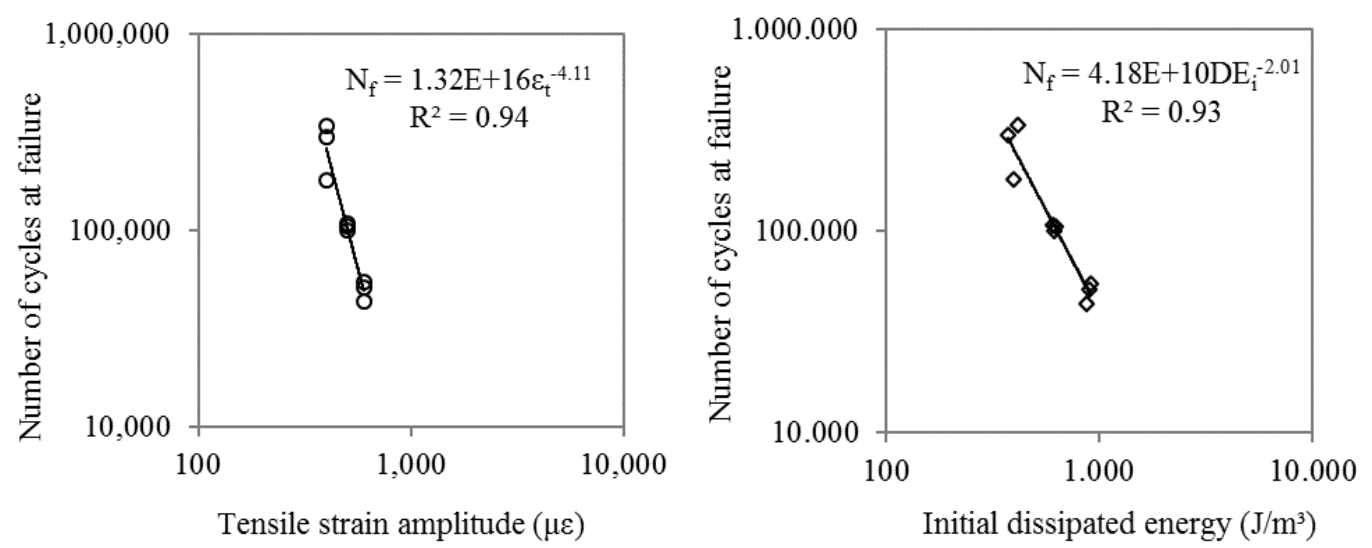

Figure 3. Number of cycles at failure versus tensile strain amplitude and initial dissipated energy for 4PBB fatigue tests 
The 4PBB fatigue tests performed on the mixture used on the experimental segment show a low variability with small coefficient of variation. Both fatigue models, considering tensile strain and dissipated energy, show a good fitting to the data, with coefficients of determination $\left(\mathrm{R}^{2}\right)$ of 0.94 and 0.93 , respectively.

The hysteresis loops obtained for the 4PBB test with peak to peak strain of $500 \mu \varepsilon$ is pictured on Figure 4. The loop area represents the dissipated energy due to dissipative phenomena as plastic dissipation and, mainly, damage growth.

The dissipated energy changes continuously along the fatigue process as the number of cycles increase, and the cracks initiate and propagate. In Figure 4 it can be observed a decrease in the loop area (i. e. energy) as the number of cycles increase, it happens as a consequence of the modulus reduction in the material throughout the test, in which the stress decreases to keep the displacement amplitude constant. The dissipated energy vs number of cycles can be fitted by a power function, as shown in Figure 5.

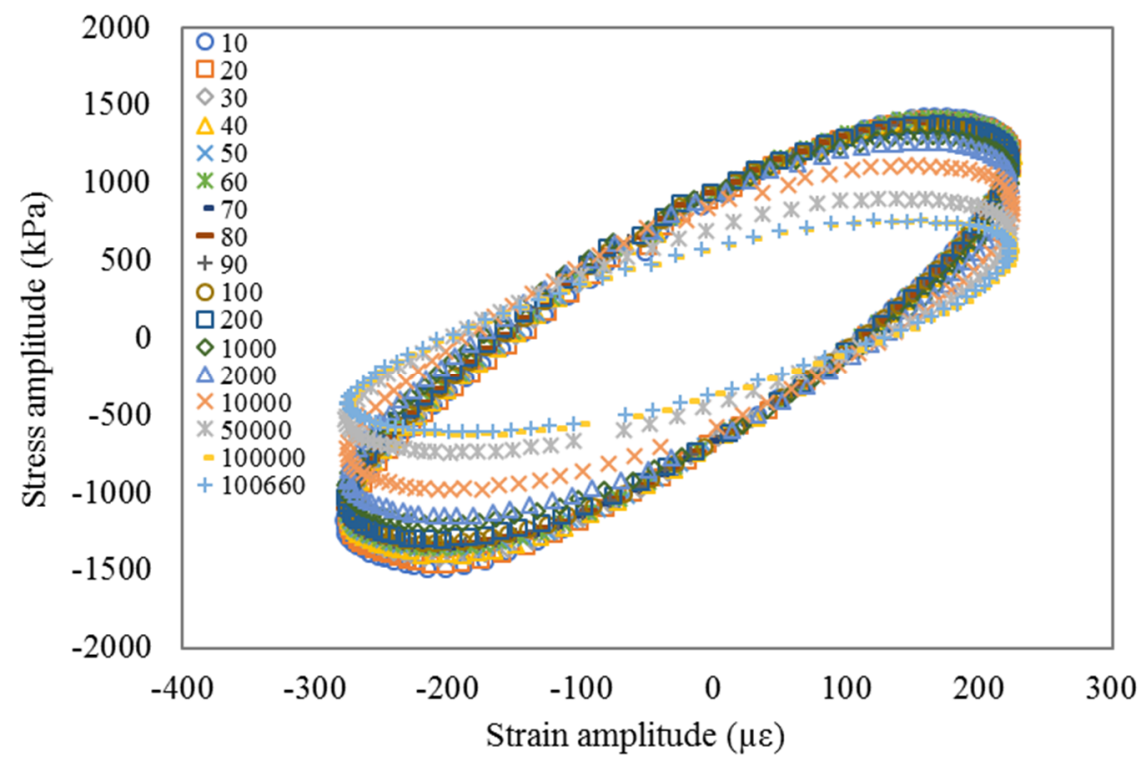

Figure 4. Typical stress-strain hysteresis loop for different number of cycles (4PBBT)

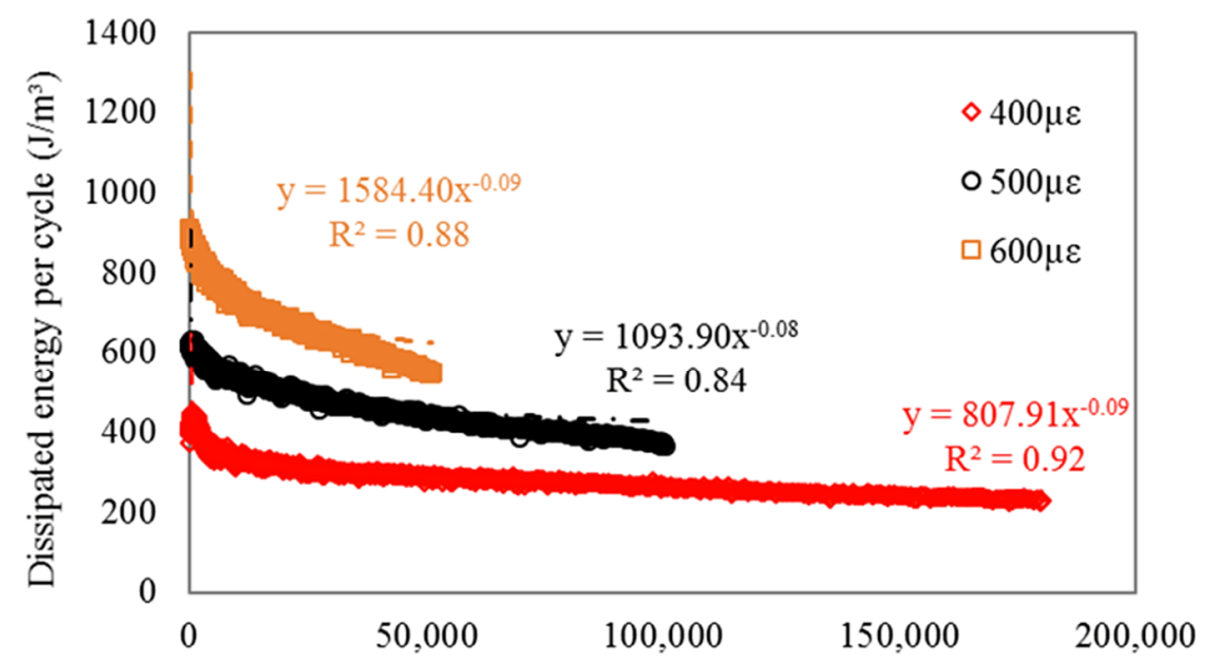

Number of cycles

Figure 5. Dissipated energy versus number of cycle for different strain peak 
The IDT fatigue tests results are shown on Table 2. The Figure 6 presents the fatigue curve of IDT fatigue tests.

Table 2 - Results of fatigue test for IDT testing method

\begin{tabular}{|c|c|c|c|c|c|c|c|c|c|}
\hline \multirow[b]{2}{*}{ Sample } & \multirow{2}{*}{$\begin{array}{c}\text { Air } \\
\text { voids } \\
(\%)\end{array}$} & \multirow{2}{*}{$\begin{array}{c}\text { Stress } \\
\text { level } \\
(\%)\end{array}$} & \multirow{2}{*}{$\begin{array}{c}\text { Tensile } \\
\text { stress } \\
\text { level } \\
(\mathrm{kPa}) \\
\end{array}$} & \multicolumn{3}{|c|}{ Initial resilient modulus } & \multicolumn{3}{|c|}{ Number of cycles at failure $\left(\mathrm{Nf}_{50 \%}\right)$} \\
\hline & & & & $\begin{array}{l}\text { Initial resilient modu- } \\
\text { lus (MPa) }\end{array}$ & Average & $\begin{array}{l}\text { COV } \\
(\%)\end{array}$ & $\left(\mathrm{Nf}_{50 \%}\right)$ & Average & $\operatorname{cov}(\%)$ \\
\hline 1 & 4.0 & 10 & & 5288 & & & $8.46 \mathrm{E}+04$ & & \\
\hline 2 & 4.0 & 10 & 140 & 4267 & $47 / 8$ & 15.1 & $8.42 E+04$ & $8.44 \mathrm{E}+04$ & 0.3 \\
\hline 3 & 4.1 & 20 & 290 & 2591 & 2712 & 63 & $4.33 \mathrm{E}+03$ & $520 F+03$ & \\
\hline 4 & 4.1 & 20 & 290 & 2833 & & 6.3 & $6.06 \mathrm{E}+03$ & $3.20 t+03$ & 23.6 \\
\hline 5 & 4.1 & 30 & & 2334 & & & $2.06 \mathrm{E}+03$ & & \\
\hline 6 & 4.1 & 30 & 430 & 2468 & 2401 & 3.9 & $8.87 E+02$ & $1.4 / \mathrm{t}+03$ & 56.2 \\
\hline 7 & 4.3 & 40 & $57-2+3$ & 2621 & 2271 & & $2.63 \mathrm{E}+02$ & ? & 60 \\
\hline 8 & 4.3 & 40 & $5 / 0$ & 2120 & $23 / 1$ & 14.9 & $6.54 \mathrm{E}+02$ & 4.5 & 60.3 \\
\hline 9 & 4.4 & 50 & 720 & 1796 & - & - & $1.40 \mathrm{E}+02$ & - & - \\
\hline
\end{tabular}

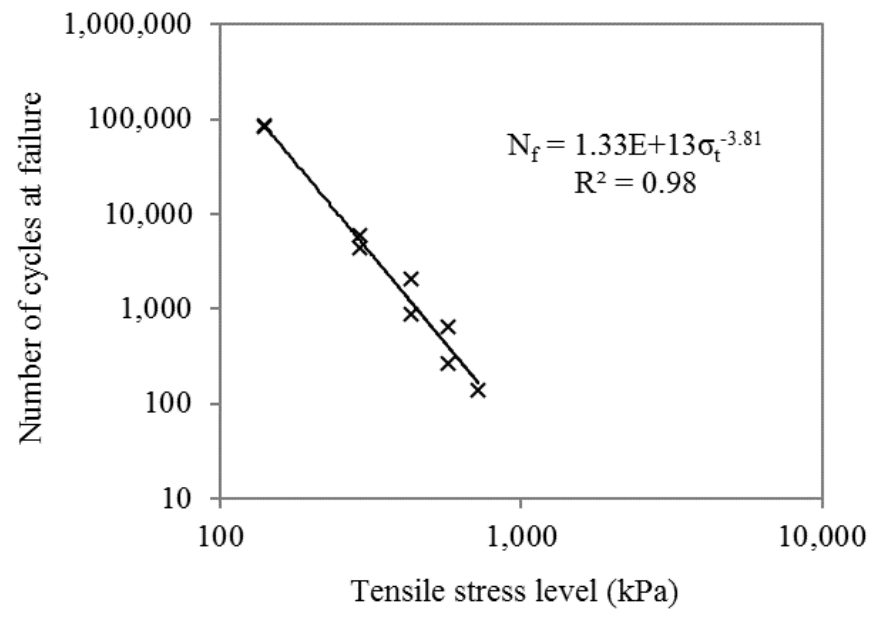

Figure 6. Fatigue curve for IDT fatigue tests

The results for IDT fatigue tests shown high coefficients of variation, which can be accredited to the instability promoted by the coring bit used to extract the specimens from the road segment, and also by the severe loads applied, once the coefficient is higher for higher loads. Despite the variation, the coefficient of determination for the fitting is high $\left(\mathrm{R}^{2}=0.98\right)$.

The hysteresis loops obtained for an IDT test under controlled stress mode (stress level equivalent to $20 \%$ of ITS) is pictured on Figure 7 . The energy increases with growing number of cycles due to a combined effect of strain increase, due to material's micro cracking yielding to stiffness reduction, while stress is kept constant (Brito et al., 2008). It can be observed that in this test configuration there is an important strain accumulation on the material from cycle to cycle, this creep also contributes to damage. In IDT tests for viscoelastic materials is not possible to separate the creep damage from the cyclic loading.

The different nature on how stresses and temperatures are combined in a scattered fashion in a real pavement create an unorderly fatigue development, as opposed to the laboratory. In IDT, strains increase constantly along the test, under controlled stress level, whereas in 4PBB, stresses decrease along the test, under a constant amplitude of controlled strain, in both scenarios resulting in stiffness reduction due to materials' integrity degradation. 


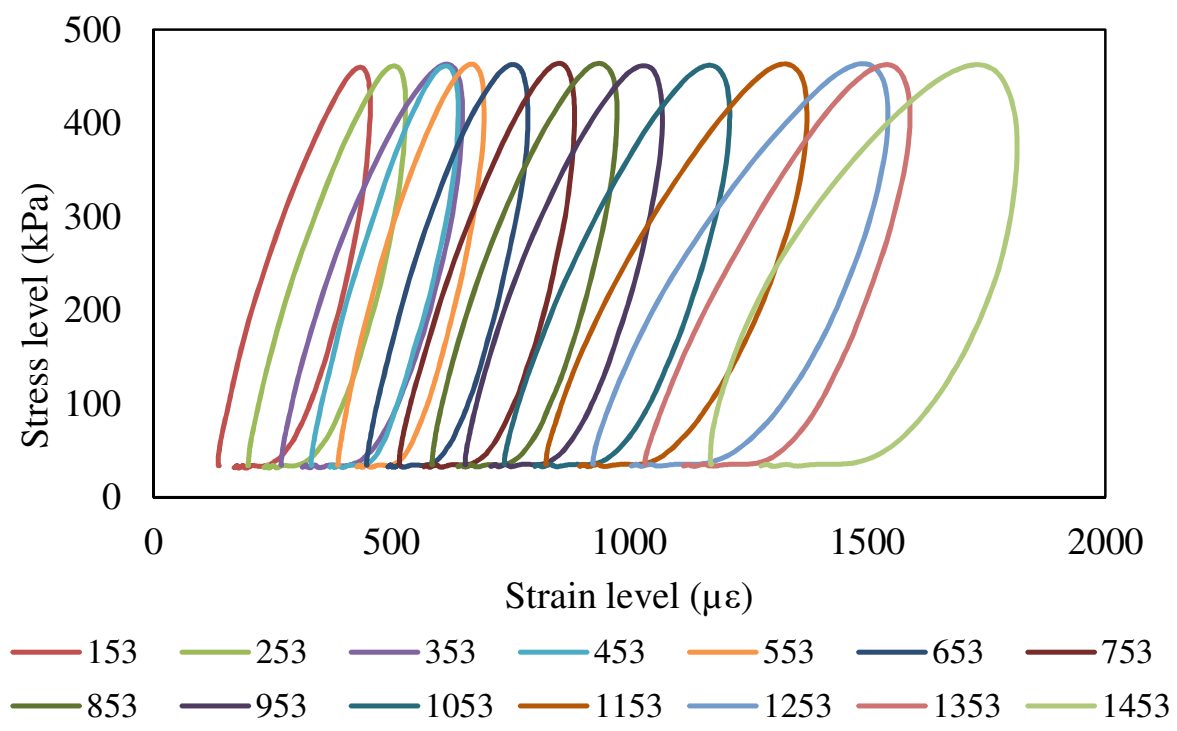

Figure 7. Typical stress-strain hysteresis loop for different number of cycles (IDT)

Fatigue results are typically adjusted by a function which relates the effort imposed in the test to the number of cycles at fatigue failure. However, knowing the actual effort induced in the field is important to determine in which level the fatigue behavior should be analyzed, since the laboratory tests are carried out in different levels.

\subsection{Signal processing - field data}

The longitudinal strain gage shows alternate signal of contraction and extension, due to dynamic nature of the loads, which impose different efforts depending on the position of gage in relation to the axle, while the transversal strain is always extension and the vertical stress is always compression (Perret, 2003).

To validate the field signals, some modelling were carried out using the software 3D-MOVE. The pavement parameters used in the analysis are shown in Table 3.

Table 3 - Material properties and layers thickness used in 3D-MOVE

\begin{tabular}{ccccc}
\hline Material & Behavior & Thickness $(\mathrm{mm})$ & Resilient Modulus (MPa) & Poisson's ratio \\
\hline Bituminous layer & Linear elastic/viscoelastic & 80 & Dynamic Modulus & 0.30 \\
Granular base & Linear elastic & 150 & 261 & 0.35 \\
Granular subbase & Linear elastic & 300 & 291 & 0.35 \\
Subgrade & Linear elastic & - & 134 & 0.40 \\
\hline
\end{tabular}

The longitudinal and transversal strain, and vertical pressure obtained from the instrumentation as well as from 3D-MOVE software are presented in Figure 7, for a single axle dual tires load with tire pressure of $560 \mathrm{kPa}$, speed of $80 \mathrm{~km} / \mathrm{h}$ and temperature of $32^{\circ} \mathrm{C}$, for the asphalt layer. This temperature is based on the thermocouples reading embedded on the layer for the average temperature on which most of the readings were registered.

The simulated pavement responses are consistent with the field measurements, which validates the data acquisition system. Regarding the shape of the signal, the vertical stress, transversal strain and longitudinal strain shows a better match for the set of data collected from the 
instrumentation than the signal magnitude, which can be attributed to the axle position in relation to the sensors. According with Leandri et al. (2013), for little errors in the measurement of the relative position, the difference in the simulation can be high. The shape of stress load measured by the pressure cell (PC) shows a difference on the unloading path compared to the simulated data (Figure 8a). The shape of unloading path is related to the relaxation behavior of the asphalt materials and the observed difference can be either a data acquisition problem or an inability of the software to describe well this phenomenon of viscoelastic materials. Further investigation should be addressed to account for this difference.

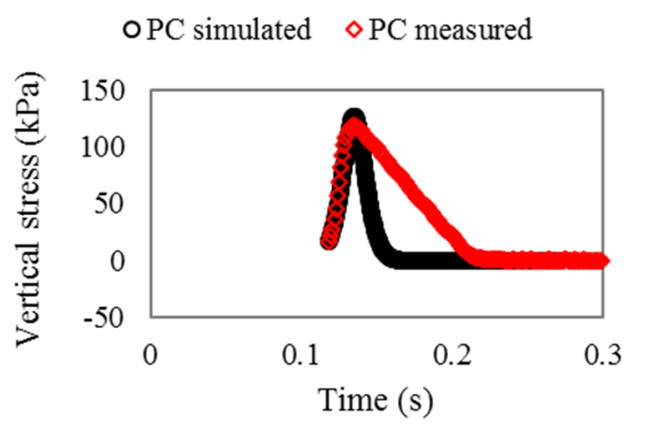

(a)

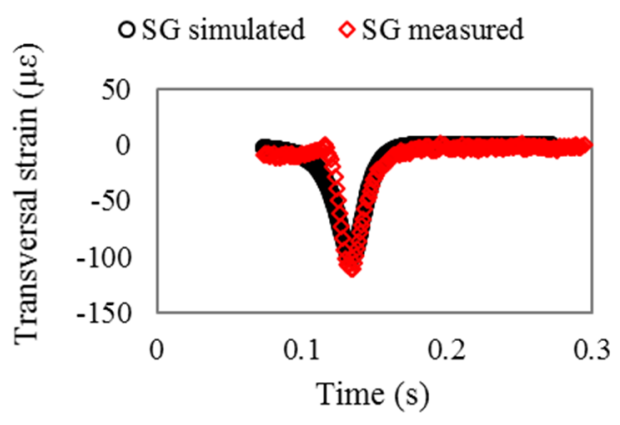

(b)

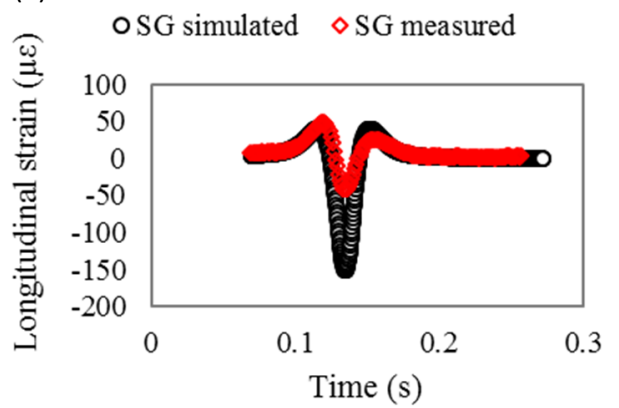

(c)

Figure 8. Vertical pressure (a), transversal strain (b) and longitudinal strain (c) simulated on 3D-MOVE and measured from the pavement structure

The simulated pavement responses are consistent with the field measurements, which validates the data acquisition system. Regarding the shape of the signal, the vertical stress, transversal strain and longitudinal strain shows a better match for the set of data collected from the instrumentation than the signal magnitude, which can be attributed to the axle position in relation to the sensors. According with Leandri et al. (2013), for little errors in the measurement of the relative position, the difference in the simulation can be high. The shape of stress load measured by the pressure cell (PC) shows a difference on the unloading path compared to the simulated data (Figure 8a). The shape of unloading path is related to the relaxation behavior of the asphalt materials and the observed difference can be either a data acquisition problem or an inability of the software to describe well this phenomenon of viscoelastic materials. Further investigation should be addressed to account for this difference

\subsection{BR-116 Field Results}

A series of 3000 events were collected to determine the level of stress and strains developed in the bottom of asphalt layer. The results (Figure 9) demonstrates that the longitudinal strains and vertical stresses rarely exceed 250 microstrains and $400 \mathrm{kPa}$, respectively. A "zero" vertical 
stress and "zero" longitudinal strain in Fgiure 9, means 0 to 50 stress or strain reading; it is likely these readings are produced by light vehicles or high stress contact loads further away from sensors.

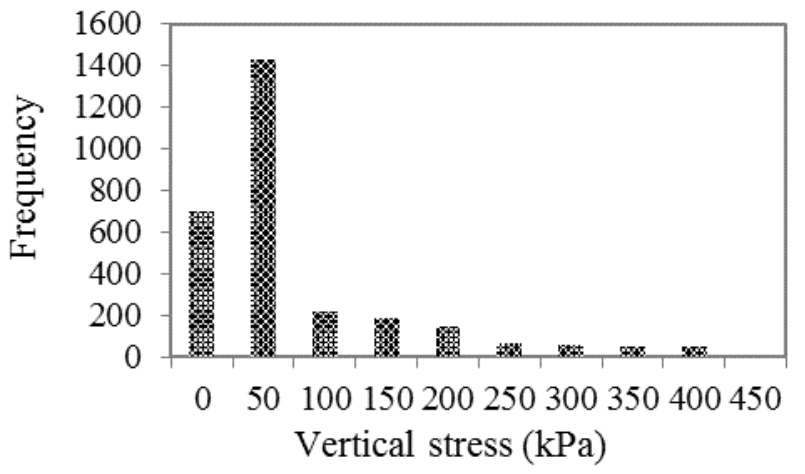

(a)

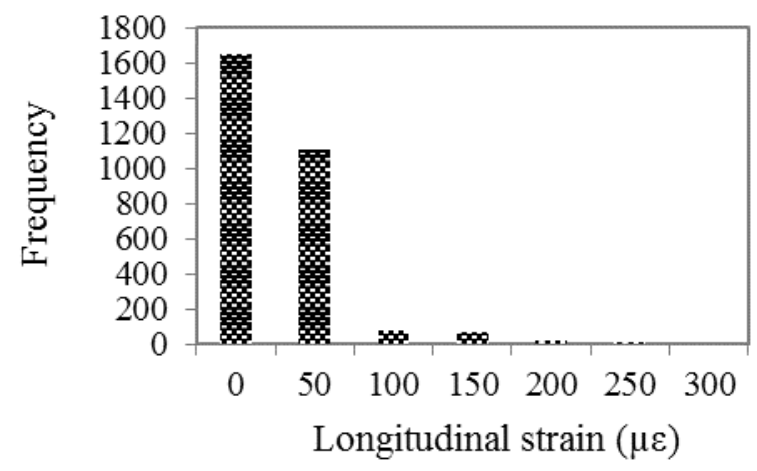

(b)

Figure 9. Series of events collected for stress (a) and strain (b) in the bottom of asphalt layer

In laboratory, the strain level is usually higher than those obtained from field data, to make the tests faster. In the strain level observed in field data (less than $250 \mu \varepsilon$ ), the 4PBB shows a number of cycles to fatigue failure of $1.81^{*} 10^{6}$, while IDT shows a number of cycles to fatigue failure of $1.62 * 10^{3}$ (for a stress of $400 \mathrm{kPa}$ ), according to the fatigue models calibrated for the mixtures in this study.

The number of repetitions of a standard axle $(\mathrm{N})$ in the road segment during the trial period, based on the American Association of State Highway and Transportation Officials (AASHTO) equivalent factors, was of $1.05^{*} 10^{6}$ ESALs. This value is higher than the $\mathrm{N}_{\mathrm{f}}$ obtained from fatigue tests, even considering the same tensile strain observed in field; nonetheless, the pavement section did not develop any visible superficial cracks during the trial period. Such difference corroborates to the importance of a correlation factor, or transfer function, from the laboratory to field result (Priest, 2005; Nascimento, 2015; Fritzen, 2016).

Considering a shift-factor of "4" to 4PBB tests (Mateos et al., 2011) and "104" for IDT tests (Pinto, 1991), from literature, the number of cycles at failure would be $7.24^{*} 10^{6}$ and $6.41^{*} 10^{7}$, respectively, for 250 microstrains and $400 \mathrm{kPa}$. A 4PBB approximation would suggest a pavement outlasting 6,9 times more traffic than that from the trial period, while an IDT fatigue life would suggest 61 times more traffic until pavement failed due to fatigue cracking. Although results are not shown in this research, the continuous monitoring of the section assured a much better correlation to the 4 PBB estimate.

\section{CONCLUSIONS}

The primary goal of this research was to draw a comparison between 4PBB and IDT fatigue tests results supported by an in situ instrumented test section. In order to accomplish the task, conceiving a reliable instrumentation capable of coping with real traffic condition was prime.

The data acquisition system developed has proved to be effective and the readings were reliable, highlighting a good adherence between modelled and collected results. The filtering and pre-processing of signals allowed a loading wave shape without distortions and interferences, therefore becoming easily understandable and interpretable. The algorithm for identification of a new event (vehicle hit) is also adequate, showing a good sensibility for this application and optimizing data collection size. 
The fatigue tests protocols used for the research demonstrated to produce good quality results. Regardless the aforementioned issues with IDT test configuration, the strain measurement allows for further analysis, such as dissipated energy calculation, which traditionally is not possible. The availability of a fatigue model for the 4PBB test using the dissipated energy concept turns available further discussion of the better correlation of this test to field data.

Finally, although the pavement structure displayed a longer fatigue life span than laboratory tests, the 4PBB had a closer relation to field performance in comparison to IDT fatigue tests.

\section{ACKNOWLEDGEMENTS}

The authors wish to express their gratitude for the LAPAV-UFRGS, UERGS, Triunfo|Concepa Concessionary, National Agency for Terrestrial Transportation (ANTT) and all other laboratory partners for their technical contribution and financial support to the research group.

\section{REFERENCES}

AASHTO (2014) T321 - Determining the Fatigue Life of Compacted Hot-Mix Asphalt (HMA) Subjected to Repeated Flexural Bending. American Association of State Highway and Transportation Officials, Washington, D.C.

Al-Qadi, I. L.; Nassar, W. N. (2003) Fatigue Shift Factors to Predict HMA Performance. The International Journal of Pavement Engineering, vol. 4, p. 69-75.

Bastos, J. B. S. (2016) Considerações sobre a Deformação Permanente de Pavimentos Asfálticos no Dimensionamento Mecanístico-empírico. Tese (Doutorado em Engenharia), Universidade Federal do Ceará, Fortaleza.

Bessa, I. S. (2017) Laboratory and Field Study of Fatigue Cracking Prediction in Asphalt Pavements. Dissertation (Doctor of Science), Escola Politécnica of the Universidade de São Paulo, São Paulo.

Brito, L. A. T; Ceratti, J. A. P.; Victorino, D. R. (2008) Indicadores do Desempenho de Misturas Asfálticas Determinados através do Ensaio de Compressão Diametral. Revista Transportes (Rio de Janeiro), v. 16, p. 36-44. http://dx.doi.org/10.14295/transportes.v16i1.10.

Brown, S. F. (1977) State-of-the-art Report on Field Instrumentation for Pavement Experiments. Transportation Research Record, no 640 , p. $13-28$.

Ceratti, J. A. P.; Brito, L. A. T.; Colpo, G. B.; Doering, D. (2017) Instrumentação In Situ de um Segmento da BR-116 - Estudo Comparativo do Efeito Laboratório-campo da Fadiga. Concepa/ANTT, Recursos para Desenvolvimento Tecnológico - RDT.

Chaves, J. M. et al. (2016) Desenvolvimento do Modelo de Deterioração de Pavimentos Asfálticos com Uso de Instrumentação e Sistema Weight in Motion. Autopista Fernão Dias/ANTT, Recursos para Desenvolvimento Tecnológico - RDT, Projeto 06, SGP/AFD_06 REV.0.

Colpo, G. B. (2014) Análise de Fadiga de Misturas Asfálticas Através do Ensaio de Flexão em Viga Quatro Pontos. Dissertação (Mestrado em Engenharia) - Universidade Federal do Rio Grande do Sul, Porto Alegre.

Di Benedetto, H.; De La Roche, C.; Baaj, H.; Pronk, A.; Lundström, R. (2004) Fatigue of Bituminous Mixtures. Materials and Structures, vol. 37, p. 202-216.

Dondi, G.; Pettinari, M.; Sangiorgi, C.; Zoorob, S. E. (2013) Traditional and Dissipated Energy Approaches to Compare the 2PB and 4PB Flexural Methodologies on a Warm Mix Asphalt. Construction and Building Materials, vol. 47, p. 833-839.

Fritzen, M. A. (2016) Desenvolvimento e Validação de Função de Transferência para Previsão do Dano por Fadiga em Pavimentos Asfálticos. Tese (Doutorado em Engenharia). Universidade Federal do Rio de Janeiro - UFRJ/COPPE. Rio de Janeiro.

Garg, N.; Li, Q.; Haggag, M. (2018) Accelerated Pavement Testing of Perpetual Pavement Test Sections under Heavy Aircraft Loading at FAA's National Airport Pavement Test Facility. International Society for Asphalt Pavements - ISAP Conference, Fortaleza, Ceará, Brazil.

Ghuzlan, K. A., Carpenter. (2000) Energy-Derived, Damage-Based Failure Criterion for Fatigue Testing. Transportation Research Record, Journal of the Transportation Research Board, no 1723, Washington, D.C., p. 141-149. DOI: 10.3141/1723-18.

Gonçalves, F. J. P. (2002) Estudo do Desempenho de Pavimentos Flexíveis a partir de Instrumentação e Ensaios Acelerados. Tese (Doutorado em Engenharia). Universidade Federal do Rio Grande do Sul, Porto Alegre.

Harvey, J. T., Deacon, J. A., Tsai, B-W.; Monismith, C. L. (1995) Fatigue Performance of Asphalt Concrete Mixes and its Relationship to Asphalt Concrete Pavement Performance in California. Report Prepared for California Department of Transportation, № RTA-65W48-2, Asphalt Research Program, Institute of Transportation Studies, University of California, Berkeley.

Kim, Y. R.; Lee, H. J.; Little, D. N. (1997) Fatigue Characterization of Asphalt Concrete Using Viscoelasticity and Continuum Damage Theory. Journal of the Association of Asphalt Paving Technologists, vol. 66, p. 633-685.

Klinsky, L.; Faria, V.; Oda, S.; Cavalcanti, L.; Barella, R. (2014) Avaliação da influência do tipo de ligante asfáltico na vida de fadiga de misturas asfálticas. In: Encontro do Asfalto, 21, Rio de Janeiro, IBP.

Leandri, P.; Bacci, R.; Di Natale, A.; Rocchio, P.; Losa, M. (2013) Appropriate and Reliable use of Pavement Instrumentation on Inservice Roads. Airfield and Highway Pavement 2013: Sustainable and Efficient Pavements, pp. 1424-1433.

Leiva-Villacorta, F.; Timm, D. H. (2012) Simulating the Effects of Instrumentation on Measured Pavement Response. Advances in Pavement Design through Full-scale Accelerated Pavement Testing. Taylor \& Francis Group, pp. 153-161. 
Mateos, A., Ayuso, J. P., Cadavid, B. (2011) Shift Factors for Asphalt Fatigue from Full-scale Testing. Annual Meeting of the Transportation Research Board, CEDEX Transport Research Center.

Mateos, A.; Ayuso, J. P.; Cadavid, B. (2011) Shift factors for Asphalt Fatigue from Full-scale Testing. Annual Meeting of the Transportation Research Board, CEDEX Transport Research Center.

Mateos, A.; Wu, R.; Harvey, J.; Denneman, E.; Fan, A. (2017) The Logit Model and the Need to Reproduce the Stiffness Degradation Curve of Asphalt Specimens During Fatigue Testing. Transportation Research Record: Journal of the Transportation Research Board, no 2631, p. 105-113.

Matthews, J. M.; Monismith, C. L.; Craus, J. (1993) Investigation of Laboratory Fatigue Testing Procedures for Asphalt Aggregate Mixtures. Journal of Transportation Engineering, vol. 119, p. 634-654, 1993.

Melo, J. V. S. de. (2014) Desenvolvimento e Estudo do Comportamento Reológico e Desempenho Mecânico de Concretos Asfálticos Modificados com Nanocompósitos. Tese (Doutorado em Engenharia). Universidade Federal de Santa Catarina, Santa Catariana.

Nascimento, L. A. H. do. (2015) Implementation and Validation of the Viscoelastic Continuum Damage Theory for Asphalt Mixture and Pavement Analysis in Brazil. Dissertation (Doctor of Philosophy). Faculty of North Carolina State University. Transportation Materials. Raleigh, North Carolina - USA.

Pell, P. S.; Mccarthy, P. F.; Gardner, R. R. (1961) Fatigue of Bitumen and Bituminous Mixes. International Journal of Mechanical Sciences. vol. 3, p. 247-267.

Perret, J. (2003) Déformations des Couches Bitumineuses au Passage D’une Charge de Trafic. Tese (Doutorado em Engenharia Civil). École Polytechnique Fédérale de Lausanne, Lausanne.

Pinto, S. (1991) Estudo do Comportamento à Fadiga de Misturas Betuminosas e Aplicação na Avaliação Estrutural de Pavimentos. Tese (Doutorado em Engenharia) - Universidade Federal do Rio de Janeiro, Rio de Janeiro.

Preussler, E. S.; Pinto, S.; Medina, J. (1981) Determinação da Vida de Fadiga de Concretos Asfálticos Brasileiros e Aplicação no Dimensionamento de Reforço de Pavimentos. Reunião Anual de Pavimentação, 16. Recife: ABPV.

Priest, A. L. (2005) Calibration of Fatigue Transfer Functions for Mechanistic-empirical Flexible Pavement Design. Thesis (Masters of Science). Faculty of Auburn University, Aubum, Alabama.

Priest, A. L; Timm, D. H. (2006) Methodology and Calibration of Fatigue Transfer Functions for Mechanistic-Empirical Flexible Pavement Design. National Center for Asphalt Technology, NCAT, Auburn University, NCAT Report 06-03.

Rahbar-Rastegar, R.; Daniel, J. S. (2016) Laboratory versus Plant Production: Impact of Material Properties and Performance for RAP and RAS Mixtures. International Journal of Pavement Engineering. pp. 1-12.

Rowe, G. M. (1996) Application of the Dissipated Energy Concept to Fatigue Cracking in Asphalt Pavements. PhD Thesis, University of Nottingham, Nottingham.

Shen, S.; Carpenter, S. H. (2005) Application of Dissipated Energy Concept in Fatigue Endurance Limit Testing. Transportation Research Record, Journal of the Transportation Research Board, no 1929, Washington, D.C., p. 165-173.

Shen, S.; Carpenter, S. H. (2007) Dissipated Energy Concepts for HMA Performance: Fatigue and Healing. COE report n⿳丷. 29. Center of Excellence for Airport Technology, Department of Civil and Environmental Engineering, University of Illinois at Urbana-Champaign, Champaign-Urbana Metropolitan Area, Illinois, USA.

Shen, S; Airey, G. D.; Carpenter, S. H.; Huang, H. A. (2006) Dissipated Energy Approach to Fatigue Evaluation. Road Materials and Pavement Design, vol. 7, p. 47-69. Doi: 10.1080/14680629.2006.9690026.

Silva, P. D. E. A.; Motta, L. M. G. (1999) Instrumentação da Pista Circular Experimental do IPR/DNER. Transportes, vol. 7, no 2, p. 29-46.

Subhy, A.; Presti, D. L.; Airey, G. (2017) New Simplified Approach for Obtaining a Reliable Plateau Value in Fatigue Analysis of Bituminous Materials. Engineering Failure Analysis. Doi: 10.1016/j.engfailanal.2017.05.021.

Tabatabafe, N.; Sebaaly, P. (1990) State-of-the-art: Pavement Instrumentation. Transportation Research Record, no 1260, p. 246-255.

Tangella, S. C. S. R., Craus, J., Deacon, J. A.; Monismith, C. L. (1990) Summary Report on Fatigue Response of Asphalt Mixtures. Prepared for Strategic Highway Research Program, Project A-003-A. Institute of Transportation Studies, University of California, Berkeley.

Tapsoba, N.; Sauzéat, C.; Di Benedetto, H. (2013) Analysis of Fatigue Test for Bituminous Mixtures. Journal of Materials in Civil Engineering, vol. 25, p. 701-710. DOI: 10.1061/(ASCE)MT.1943-5533.0000636.

Tayebali, A. A.; Deacon, J. A.; Coplantz, J. S.; Finn, F. N.; Monismith, C. L. (1994) Fatigue Response of Asphalt Aggregate Mixtures, Part I e II. Strategy Highway Research Program, Project A-404. Asphalt Research Program, Institute of Transportation Studies, University of California.

Timm, D. H.; Priest, A. L.; Mcewen, T. V. (2004) Design and Instrumentation of the Structural Pavement Experiment at the NCAT Test Track. National Center for Asphalt Technology, NCAT, Auburn University, NCAT Report 04-01.

Ullidtz, P.; Harvey, J.; Tsai, B.-W.; Monismith, C. L. (2006) Calibration of CalME Models using WesTrack Performance Data. California Department of Transportation Division of Research and Innovation Office of Roadway Research, Report no UCPRCRR-2006-14.

Van Deusen, D. A.; Newcomb, D. E.; Labuz, J. F. (1992) A Review of Instrumentation Technology for the Minnesota Road Research Project. University of Minnesota.

Xiao, F. (2006) Development of Fatigue Predictive Models of Rubberized Asphalt Concrete (RAC) Containing Reclaimed Asphalt Pavement (RAP). Dissertation (Doctor of Philosophy). Clemson University, Clemson. 
Zejiao, D.; Yiqiu, T.; Meili, L. (2012) Design and Implementation of a Full-scale Accelerated Pavement Testing Facility for Extreme Regional Climates in China. Advances in Pavement Design through Full-scale Accelerated Pavement Testing. Taylor \& Francis Group, pp. 39-45. 